\title{
Abstracts
}

Edgar Grande / Thomas Risse

Bridging the Gap

Conceptual Challenges for the Analysis of Globalization

Processes in Political Science

ZIB, Vol. 7, No. 2, pp. 235-266

This special issue brings together analysts from various subdisciplines of political science to discuss the effects of globalization on the action capacities of nation-states. The challenges of globalization render the specialization in various subdisciplines of political science problematic. The emergence of synthetic analytical approaches which transcend simplistic distinctions between »domestic « and »international« as well as between »state « and »society « calls for a convergence of research questions in political science. Empirical research has shown that globalization by no means leads to the obsolescence of nation-states, but rather to their transformation into complex networks of global governance. This raises the question, how globalization expands or constrains the choices of political actors on the one hand, and how it affects the problem-solving capacity of complex governance structures on the other hand. First, we review the political science literature on the effects of globalization on the nation-state and its action capacity. Second, we discuss theoretical developments in the subdisciplines of political sciences over the past 20 years demonstrating a convergence toward synthetic approaches. We then deal with the conceptual challenges of globalization for political science and refine the question about the action capacieties of nation-states in order to avoid unnecessary controversies. 


\title{
Philipp Genschel
}

\section{Tax Competition and the Welfare State}

\author{
ZIB, Vol. 7, No. 2, pp. 267-296
}

Does globalization undermine the fiscal basis of the welfare state? The conventional wisdom seems to believe so: open borders invite tax competition, which in turn erodes the revenues from capital taxation. However, there is little evidence to support this view. The data show that revenues from capital taxation are fairly stable in OECD countries. Some observers conclude from this that globalization is not much of a challenge to the welfare state. In this article, I argue that both positions have the same weakness: they ignore the fact that globalization was not the only challenge that the welfare state had to deal with in the 1980s and 1990s. There was also slow growth, rampant unemployment, and high levels of precommitted spending. The welfare state is not caught up in a race to the bottom, but trapped in between external pressures to reduce the tax burden on capital on the one hand, and internal pressures to maintain revenue levels and relieve the tax burden on labor on the other.

Michael Zuern / Gregor Walter / Sabine Dreher / Marianne Beisheim

\section{Postnational Politics?}

Political Responses to Denationalization Challenges caused

by the Internet, Climate Change and Migration

ZIB, Vol. 7, No. 2, pp. 297-329

In the debate on the consequences of globalization it is often assumed that this process directly and sometimes even uniformly affects state policies. By contrast, this article argues that in order to understand the political consequences of societal denationalization it is also necessary to consider its effects on politics. It is therefore necessary to enquire how denationalization challenges affect the participation of relevant societal actors in processes of political will-formation and decision-making in national political systems. In an attempt to do so the responses of national interest-groups to denationalization challenges in each of the issue areas Internet, climate change and migration are analyzed in two countries of the G7. The results show that in comparison to traditional patterns, there have been significant changes in group's positions decision-making processes, especially for highly denationalized challenges. While the nation-state remains the central target and focus of political acitivites, however, its function seems to change. 


\section{Andreas Noelke}

\section{Governance by Transnational Policy Networks?}

A Critical Appraisal of Post-national Governance Approaches from the Perspective of a Transnational Sociology of Organizations

ZIB, Vol. 7, No. 2, pp. 331-358

Transnational policy networks appear to be an attractive common subject of both Public Policy and International Relations, if we are interested in the consequences of globalization on public policy-making capacities. The article focuses on the confrontation between approaches which propose these networks as a new governance instrument and a more critical analytical perspective. Based on a theoretical model that analyzes transnational policy networks as inter-organizational resource exchanges, empirical illustrations from the following research areas are presented: cooperation in border regions, transnational advocacy NGOs in human rights protection and multi-level governance in the European Union. The article concludes that transnational policy networks are only relevant under very specific empirical conditions. Furthermore, the possibility to regulate these networks is severely limited. Finally, transnational policy networks raise important questions of democratic legitimacy.

\section{Klaus Schlichte / Boris Wilke}

\section{The State and Some of its Contemporaries}

On the Future of Governance in the »Third World«

\section{ZIB, Vol. 7, No. 2, pp. 359-384}

The novelty and the reality of the phenomenon called »globalization « is a matter of long discussion. Third World states, however, have always been shaped externally and their consolidation has always been precarious. But in recent years there seem to appear profound changes in the mode of government in these states. This article attempts to summarize these changes based on the theses of an increasing role of informal arrangements, of an increase in intermediary rule and the bifurcation of security systems. It is a question of interpretation whether these new forms herald a loss of state authority or rather the redeployment of the state. It can be taken as fact, though, that these changes are possible because changes in the international context offer new opportunities for all parties involved. Any effort to establish international forms of »governance « has to take into account the fact that due to these changes Third World states are less able to fulfill a pivotal function. 
Wolfgang Fach / Georg Simonis

The Author and His World

A Polemic

ZIB, Vol 7, No. 2, pp. 385-398

Political scientists, eager to solve »real« problems, tend to adopt the philosophy of those who are in power and ready for action. This pragmatic attitude, however commendable it may be, comes at a price - the loss of intellectual coolness, often mistaken for »cynical reason«. »Cool« theory is open to a broad range of controversial issues played down or brushed off by »sweating « pragmatists. Think of repression, violence, exploitation, destruction, despair, racism, or chauvinism. This is not to imply that these paralyzing facts are uncontested truths; but to recall what political science - like any science - should do first and can do best: solve its own problems. Currently, it does not even face them. 